\title{
Crop and Weed Growth in Direct-Seeded Rice Cultivars as affected by Different Weed Management Practices under Rainfed Conditions of Nagaland, India
}

\author{
Noyingthung Kikon ${ }^{1}$, T. Gohain ${ }^{1}$, N. Khumdemo Ezung ${ }^{2}$ and T. Angami ${ }^{3 *}$ \\ ${ }^{1}$ SASRD, Nagaland University, Medziphema - 797106, Nagaland, India \\ ${ }^{2}$ KVK Kiphire, ICAR (Research Complex) for NEH Region, Nagaland Centre, \\ Medziphema - 797106, Nagaland, India \\ ${ }^{3}$ ICAR (Research Complex) for NEH Region, AP Centre, Basar-791101, \\ Arunachal Pradesh, India \\ *Corresponding author
}

\section{A B S T R A C T}

\begin{tabular}{|l|}
\hline Ke y w o r d s \\
$\begin{array}{l}\text { Direct-seeded rice, } \\
\text { Cultivars, Weed } \\
\text { management, Crop } \\
\text { growth, Weed growth }\end{array}$ \\
\hline Article Info \\
\hline $\begin{array}{l}\text { Accepted: } \\
\text { 07 January } 2018 \\
\text { Available Online: } \\
\text { 10 February } 2018\end{array}$ \\
\hline \hline
\end{tabular}

\section{Introduction}

Jhum cultivation is one of the major traditional agricultural land use system prevailing in the State of Nagaland. In a typical Jhum field, rice is grown as the main crop mixed with other crops and up to 6 to 7 traditional rice cultivars are cultivated in a Jhum field. Despite the rich traditional agricultural innovations the productivity of Jhum paddy is much lower compared to rice grown under terrace rice cultivation (TRC)

\begin{abstract}
Studies were conducted during the kharif season of 2009 and 2010 to study the growth of local direct-seeded rice cultivars and weeds as affected by different weed management practices under rainfed conditions of Nagaland. Results showed that the cultivars Kezie and Chongloiman recorded significantly better crop growth and yield attributes with significantly higher grain yields of $27.70 \mathrm{q} / \mathrm{ha}$ and $25.01 \mathrm{q} / \mathrm{ha}$ during 2009 and $28.27 \mathrm{q} / \mathrm{ha}$ and $26.09 \mathrm{q} / \mathrm{ha}$ during 2010 respectively. Significantly lower weed population, weed dry weight and weed relative growth rate and higher weed control efficiency were also recorded by the cultivars Kezie and Chongloiman. Among the weed management treatments, hand weeding at 20 and 40 days after sowing was found to record significantly higher weed control efficiency with significantly lower weed population and dry weight resulting in better crop growth and superior yield attributes and ultimately recording the highest grain yield of $34.21 \mathrm{q} / \mathrm{ha}$ and $35.71 \mathrm{q} /$ ha during 2009 and 2010 respectively.
\end{abstract}

and wet rice cultivation (WRC). During the year 2014-15 the average productivity of Jhum paddy was only 1.94 t/ha compared to TRC/WRC with a productivity of 2.69 t/ha (DES, 2015). Of the several reasons attributed for the low productivity of Jhum systems in the State, yield losses due to weeds and unavailability of high yielding varieties suited to Jhum situations are major constraints which needs immediate research attention. The weed problem is more severe in direct seeded upland rice than transplanted lowland 
condition because direct-seeded rice germinates together with weeds, eliminating the "head start" of transplanted seedlings. In the absence of effective weed control options, yield losses are greater in direct seeded rice than in transplanted rice (Rao et al., 2007). Under Jhum conditions, farmers rampantly follow uneconomic and environmentally unsafe weed management practices. Hence, there is an urgent need for research in this area in order to develop and standardize good weed management packages for upland farmers. A number of weed management options are available viz., cultural, mechanical, chemical, biological, etc. and based on the available resources integration of diverse technologies is essential in order to manage (Buhler et al., 2000). Hand removal of weeds still remains to be the most practical method for weed control in many developing countries. Although back breaking and laborious, hand weeding is quite effective if employed at the right time (Hooda, 2002) and is of particular importance where the terrain and climate are unsuitable for mechanised systems. Chemical weed control has become popular among farmers being the most practical, effective and economical tool of weed management in rice (Barman and Varshney, 2008). However, excessive use of herbicides causes environmental pollution and induces the proliferation of resistant weed biotypes. Hence, the combination of direct weed control methods such as herbicide use with subsequent hand weeding would be a more environment-friendly and labourefficient strategy. Correct choice of cultivar is another important factor essential for maintaining crop quality and yield. Traditional cultivars and landraces grown by local farmers have been selected and preserved over years of experience and interaction with nature and these cultivars are well adapted to the local conditions. Moreover, these landraces contain great genetic variability and can serve as a source for future rice improvement. Another important aspect for choice of cultivar is the use of competitive cultivars as a component of integrated weed management. Cultural method of weed management like the use of competitive cultivar is an attractive low cost strategy and an efficient way of delivery to farmers (Andrew et al., 2015). The morphological and physiological traits of a strongly competitive crop will enable it to capture resources from a weed and utilize resources more efficiently (Lemerle et al., 2001). Cultivar differences in weed competitiveness have been reported in many crops, including rice (Haefele et al., 2004). Hence, correct choice of cultivars not only ensures crop quality and yield but also helps the crop to get the greatest benefit from other weed control measures. Keeping in view the above facts, the following investigation was conducted to study the effect of cultivars and weed management on crop and weed growth in direct seeded upland rice.

\section{Materials and Methods}

The present study was conducted during the kharif season of 2009 and 2010 in the experimental farm of School of Agricultural Sciences and Rural Development, Nagaland University, Medziphema campus. The soil of the experimental field was sandy loam, well drained and acidic in reaction with high organic carbon content, low in available $\mathrm{N}$ and medium in available $\mathrm{P}$ and $\mathrm{K}$. The experiment was laid out in split plot design with three replications. Treatments comprised of four local direct-seeded rice cultivars viz., $\mathrm{C}_{1^{-}}$ Kezie, $\mathrm{C}_{2}$-Chongloiman, $\mathrm{C}_{3}$-Leikhumo and $\mathrm{C}_{4^{-}}$ Kotsala as main factors and three weed management treatments viz., $\mathrm{W}_{0^{-}}$-Unweeded control, $\mathrm{W}_{1}$-Hand weeding at 20 and 40 DAS (days after sowing) and $\mathrm{W}_{2}$-Pre-emergence application of Butachlor @ $1.5 \mathrm{~kg}$ a.i./ha + hand weeding at 40 DAS. The cultivars Chongloiman, Leikhumo and Kotsala were tall cultivars with long maturity duration, whereas Kezie was a semi-dwarf cultivar with medium 
maturity duration. Field preparation was done during the last week of April and May. Well decomposed farmyard manure @ 10 t/ha and NPK@ @0:20:20 kg/ha was uniformly applied to all the plots. The crop was line sown in furrows during the first week of June with a seed rate of $50 \mathrm{~kg} / \mathrm{ha}$ and maintaining a spacing of $20 \mathrm{~cm}$ inter-row and $10 \mathrm{~cm}$ interplant distance. All other agronomic and cultural practices were kept standard and uniform for all the treatments. The cultivar Kezie was harvested during the first week of October while Chongloiman, Leikhumo and Kotsala were harvested during the second week of October. Data on crop growth and yield attributes viz., plant height, number of tillers, leaf area index (LAI), plant dry weight, crop growth rate (CGR), number of panicles, filled grains per panicle, 1000 grain weight and grain yield and weed growth attributes viz., weed population, weed dry weight, relative weed growth rate (RGR) and weed control efficiency (WCE) were recorded to study the response of the crop to the different treatments. Data collected were statistically analyzed by applying the technique of analysis of variance as described by Gomez and Gomez (2010). The significant differences were tested by ' $F$ ' test. Critical difference of different groups of treatments and their interactions at 5 per cent probability level were calculated whenever ' $F$ ' test was significance.

\section{Results and Discussion}

\section{Crop growth}

Significant variations in crop growth attributes were recorded among the different cultivars (Table 1 and 2). At 30 and 60 DAS, the cultivars Leikhumo and Kotsala were at par with each other and recorded significantly taller plants compared to both Kezie and Chongloiman whereas, at 60 DAS Chongloiman was also found to record significantly taller plants compared to the cultivar Kezie. Increased plant height recorded by the cultivars Leikhumo, Kotsala and Chongloiman may be due to increased internode length or due to varietal attributes. Hussain et al., (2014) and Mohammad et al., (2002) also reported increased plant height due to internode elongation and genetic potential of the plant respectively. Number of tillers at 60 DAS was found to be significantly higher for Kezie compared to the rest of the cultivars, which may be due to availability of growth resources as well as genetic potential of the cultivar. Production rate and number of tillers per plant depends on variety, availability of water, mineral nutrients and photosynthates (Reddy and Reddy, 2010). Hussain et al., (2014) also reported that higher tiller production was due to genetic variations. Leaf area index (LAI) at flowering was also found to be significantly higher for Kezie and Chongloiman, which were at par, compared to Leikhumo and Kotsala which may be due to better utilization of growth resources resulting in higher leaf number and size. Variation in total leaf area of a plant may result from changes in leaf numbers and leaf size (Reddy and Reddy, 2010). Higher tillering exhibited by Kezie may also be attributed for higher values of LAI as recorded by the cultivar. Hussain et al., (2014) also reported that Japonica varieties showed higher number of panicles $/ \mathrm{m}_{2}$ due to more number of tillers production by these varieties. Plant dry weight at 60 DAS was significantly higher for Kezie and Chongloiman, which were at par, compared to both Leikhumo and Kotsala whereas, at 90 DAS Chongloiman recorded significantly higher plant dry weight over the rest of the cultivars. Significantly higher LAI recorded by both Kezie and Chongloiman and higher number of tillers and plant height recorded by Kezie and Chongloiman respectively may have resulted in higher dry matter production by the two cultivars. 
Hussain et al., (2014) also reported difference in dry matter production of rice due to number of tillers $/ \mathrm{m}^{2}$ and leaf area index. Owing to higher dry matter production, crop growth rate recorded at 30-60 DAS was also found to be significantly higher for the cultivars Kezie and Chongloiman. Significant variations in crop growth attributes were also recorded among the different weed management treatments (Table 1 and 2). At both 30 and 60 DAS hand weeding at 20 and 40 DAS $\left(\mathrm{W}_{1}\right)$ was found to record the highest plant height, number of tillers, LAI (at flowering) and plant dry weight compared to both application of butachlor @ $1.5 \mathrm{~kg}$ a.i./ha + hand weeding at 40 DAS $\left(\mathrm{W}_{2}\right)$ and unweeded control $\left(\mathrm{W}_{0}\right)$. Mishra (2016) also reported that hand weeding at 20 and 40 DAS proved best with respect to growth parameters viz., plant height, number of tillers, number of leaves, LAI and dry matter accumulation in direct-seeded rice. The treatment $\mathrm{W}_{2}$ was also found to record significantly higher crop growth attributes viz., plant height, number of tillers, LAI (at flowering) and plant dry weight compared to $\mathrm{W}_{0}$. Significantly superior crop growth attributes recorded by both $\mathrm{W}_{1}$ and $\mathrm{W}_{2}$ may be due to higher weed control efficiency associated with both the treatments which may have resulted in lower crop-weed competition effecting better crop growth and development. Lakshmanon et al., (1984) also reported that higher weed control efficiency favorably induces better crop growth and biomass yield. Crop CGR recorded at 30-60 DAS was also found to be significantly higher for $\mathrm{W}_{1}$ as compared to both the treatments $\mathrm{W}_{2}$ and $\mathrm{W}_{0}$ while, the treatment $\mathrm{W}_{2}$ was also found to record significantly higher crop CGR over the treatment $\mathrm{W}_{0}$. Significantly higher plant dry weight recorded by both $\mathrm{W}_{1}$ and $\mathrm{W}_{2}$ at both 30 and 60 DAS may be attributed for higher CGR at 30 to 60 DAS as recorded.

\section{Weed growth}

Twenty nine (29) weed species were identified from the experimental field out of which broadleaved weeds, grasses and sedges comprised 20, 7 and 2 species respectively. The most dominant weed species observed during both the years were Digitaria setigera Roth ex Roem. \& Schult, Cynodon dactylon (L.) Pers., Cyperus rotundus Linn., Borreria articularis (L. f.) F. N. Will., Ipomoea triloba L. and Mimosa pudica L.

Significant variations in weed growth attributes were recorded among the different cultivars (Table 3). At 30 and 60 DAS, Leikhumo recorded significantly higher weed population and weed dry weight compared to Kezie and Chongloiman, which were at par with each other whereas, the cultivar Kotsala was found to be at par with the rest of the cultivars with respect to weed population and dry weight at both the stages. The cultivars Kezie and Chongloiman were found to record significantly higher crop growth rate and dry matter accumulation during the vegetative stages, which may have resulted in early seedling vigor, ground cover and crop establishment thereby giving a competitive edge to the crop resulting in reduced weed growth. Higher tillering associated with Kezie and higher LAI associated with both Kezie and Chongloiman may also have resulted in better light interception, which is a critical factor in the process of interference between crop and weeds. Rice characteristics viz., rapid canopy ground cover during vegetative stage (Fukai, 2000), LAI and tillering (Fischer and Gibson, 2001), early biomass accumulation (Cousens et al., 2003) and early vigor (Zhao et al., 2006) has also been reported to be associated with weed competitiveness by various researchers. Relative growth rate of weeds at 30 to 60 DAS was also found to be significantly lower for the cultivars Kezie and Chongloiman, 
which were at par with each other, which may be due to the fact that both cultivars recorded significantly lower weed dry weight at both stages of observations whereas, Leikhumo and Kotsala were also at par and recorded significantly higher weed relative growth rate compared to Kezie and Chongloiman. Owing to significantly reduced weed growth, the cultivar Chongloiman recorded the highest weed control efficiency followed by Kezie whereas; the lowest weed control efficiency was recorded by the cultivar Leikhumo.

Significant variations in weed growth attributes were recorded among the different weed management treatments (Table 4). At all stages of observation, weed population and weed dry weights were recorded to be significantly higher for unweeded control $\left(\mathrm{W}_{0}\right)$ compared to the rest of the treatments. Mirza et al., (2007) also reported that weed density was significantly greater in unweeded plots than other treatments. At $30 \mathrm{DAS}$, hand weeding at 20 and 40 DAS $\left(\mathrm{W}_{1}\right)$ was found to record significantly lower weed population and dry weight as compared to application of Butachlor@1.5 kg a.i./ha + hand weeding at 40 DAS $\left(\mathrm{W}_{2}\right)$. First hand weeding at 20 DAS under the treatment $\mathrm{W}_{1}$ may have effectively controlled the growth of weeds resulting in lower weed population and dry weight at 30 DAS. Mandal et al., (1986) also reported that hand weeding was most effective in controlling all the three groups of weeds when compared with different herbicides in rice fields, while chemicals were effective in controlling specific group of weeds. Whereas, significantly higher weed growth under the treatment $\mathrm{W}_{2}$ at 30 DAS may be due to short persistence/decreasing efficiency of butachlor with the lapse of time. Saikia (1991) also reported that the residual effect of preemergence herbicide butachlor was too short to provide season long control; a follow up weeding about 30-40 days after crop emergence was needed to prevent weed emergence. At 60 DAS both the treatments $\mathrm{W}_{1}$ and $\mathrm{W}_{2}$ were at par with each other and recorded significantly lower weed population and dry weight compared to the treatment $\mathrm{W}_{0}$. Effective control of weeds in upland rice with pre-emergence application of butachlor followed by one hand weeding and two hand weedings at 20 and 40 DAS were also reported by Patel et al., (1997) and Jayadeva et al., (2011) respectively. Relative growth rate of weeds (RGR) at 30 to 60 DAS was found significantly lower for treatment $\mathrm{W}_{0}$ compared to both the treatments $\mathrm{W}_{1}$ and $\mathrm{W}_{2}$. The treatment $\mathrm{W}_{1}$ was also found to record significantly lower weed RGR compared to the treatment $\mathrm{W}_{2}$. This may be due to the fact that in case of the treatment $\mathrm{W}_{0}$ the high weed density recorded at 30 DAS may have caused a competition among the weeds resulting in a plateau thereby exhibiting lower relative growth rate at 30 to 60 DAS whereas, treatments $\mathrm{W}_{1}$ and $\mathrm{W}_{2}$ recorded significantly lower weed density and dry weight at 30 DAS which may have resulted in lower competition among the weeds and thereby relatively higher accumulation of dry matter and higher relative growth rate. When plants are widely spaced, dry matter of individual plants increase with increase in plant density. Further increase in density, increases the dry matter of individual plants at a diminishing rate. A further increase in plant population results in a plateau i.e. with increase in plant population there is no increase in dry matter per unit area (Reddy and Reddy, 2010). Owing to efficient weed control and significantly reduced weed growth, the highest weed control efficiency (WCE) was recorded by the treatment $\mathrm{W}_{1}$ followed by $\mathrm{W}_{2}$ while, the lowest WCE was recorded under the treatment $\mathrm{W}_{0}$. Ghosh (2001) also reported that the highest efficiency $(76.8 \%)$ was derived with manual weeding followed by machete $(62.5 \%)$. 
Table.1 Variation in crop growth attributes of direct-seeded rice as affected by cultivars and weed management

\begin{tabular}{|c|c|c|c|c|c|c|c|c|c|c|c|c|}
\hline \multirow[t]{3}{*}{ Treatments } & \multicolumn{4}{|c|}{ Plant height (cm) } & \multicolumn{4}{|c|}{ Number of tillers (No./m²) } & \multirow{2}{*}{\multicolumn{2}{|c|}{$\begin{array}{c}\text { LAI } \\
\text { (Flowering) }\end{array}$}} & \multirow{2}{*}{\multicolumn{2}{|c|}{$\begin{array}{c}\text { CGR } \\
\text { (30-60 DAS) }\end{array}$}} \\
\hline & \multicolumn{2}{|c|}{30 DAS } & \multicolumn{2}{|c|}{60 DAS } & \multicolumn{2}{|c|}{30 DAS } & \multicolumn{2}{|c|}{60 DAS } & & & & \\
\hline & 2009 & 2010 & 2009 & 2010 & 2009 & 2010 & 2009 & 2010 & 2009 & 2010 & 2009 & 2010 \\
\hline \multicolumn{13}{|l|}{ Cultivars: } \\
\hline $\mathrm{C}_{1}$-Kezie & 42.07 & 50.96 & 82.67 & 87.43 & 273.44 & 282.44 & 411.53 & 435.89 & 1.01 & 1.13 & 16.49 & 16.64 \\
\hline $\mathrm{C}_{2^{-}}$Chongloiman & 44.71 & 54.51 & 96.84 & 104.56 & 262.89 & 268.17 & 341.00 & 326.22 & 0.97 & 1.09 & 16.51 & 16.92 \\
\hline $\mathrm{C}_{3^{-}}$Leikhumo & 54.28 & 60.90 & 108.26 & 113.48 & 247.94 & 255.61 & 319.03 & 311.67 & 0.74 & 0.89 & 13.07 & 13.76 \\
\hline $\mathrm{C}_{4^{-}}$Kotsala & 55.16 & 62.96 & 109.50 & 115.76 & 243.44 & 251.33 & 323.75 & 299.06 & 0.77 & 0.95 & 14.77 & 15.40 \\
\hline SEd \pm & 3.63 & 2.31 & 4.22 & 4.05 & 14.93 & 17.27 & 28.33 & 27.05 & 0.04 & 0.03 & 1.24 & 1.06 \\
\hline $\mathrm{CD}(\mathrm{P}=0.05)$ & 7.91 & 5.04 & 9.19 & 8.83 & NS & NS & 61.72 & 58.93 & 0.08 & 0.07 & 2.71 & 2.30 \\
\hline \multicolumn{13}{|l|}{ Weed Management: } \\
\hline $\begin{array}{l}W_{0} \text { - Unweeded } \\
\text { control }\end{array}$ & 41.84 & 51.44 & 85.93 & 94.36 & 206.63 & 213.92 & 211.06 & 230.83 & 0.61 & 0.91 & 9.76 & 9.85 \\
\hline $\begin{array}{l}W_{1}-\text { Handweeding at } \\
20 \text { and } 40 \text { DAS }\end{array}$ & 56.07 & 64.99 & 110.96 & 115.85 & 305.00 & 308.63 & 457.60 & 473.92 & 1.04 & 1.10 & 19.62 & 19.56 \\
\hline $\begin{array}{l}W_{2-} \text { Butachlor @ } 1.5 \\
\text { kg a.i/ha + hand } \\
\text { weeding at } 40 \text { DAS }\end{array}$ & 49.26 & 55.57 & 101.05 & 105.71 & 259.17 & 270.63 & 377.81 & 324.88 & 0.97 & 1.04 & 16.24 & 17.63 \\
\hline SEd \pm & 2.51 & 1.10 & 3.32 & 3.40 & 10.64 & 10.22 & 24.08 & 20.17 & 0.09 & 0.02 & 0.58 & 0.87 \\
\hline $\mathrm{CD}(\mathrm{P}=0.05)$ & 5.11 & 2.24 & 6.77 & 6.93 & 21.68 & 20.81 & 49.06 & 41.09 & 2.76 & 0.05 & 1.19 & 1.78 \\
\hline
\end{tabular}

NS: Non-significant 
Table.2 Variation in crop growth attributes, yield and yield attributes of direct-seeded rice as affected by cultivars and weed management

\begin{tabular}{|c|c|c|c|c|c|c|c|c|c|c|c|c|}
\hline \multirow[t]{3}{*}{ Treatments } & \multicolumn{4}{|c|}{ Plant dry weight $\left(\mathrm{g} / \mathrm{m}^{2}\right)$} & \multirow{2}{*}{\multicolumn{2}{|c|}{$\begin{array}{l}\text { Number of } \\
\text { panicles } / \mathbf{m}^{2}\end{array}$}} & \multirow{2}{*}{\multicolumn{2}{|c|}{$\begin{array}{l}\text { Filled grains/ } \\
\text { panicle }\end{array}$}} & \multirow{2}{*}{\multicolumn{2}{|c|}{$\begin{array}{l}\text { 1000-grain } \\
\text { weight (g) }\end{array}$}} & \multirow{2}{*}{\multicolumn{2}{|c|}{$\begin{array}{l}\text { Grain yield } \\
\text { (q/ha) }\end{array}$}} \\
\hline & \multicolumn{2}{|c|}{60 DAS } & \multicolumn{2}{|c|}{90 DAS } & & & & & & & & \\
\hline & 2009 & 2010 & 2009 & 2010 & 2009 & 2010 & 2009 & 2010 & 2009 & 2010 & 2009 & 2010 \\
\hline \multicolumn{13}{|l|}{ Cultivars: } \\
\hline $\mathrm{C}_{1}$-Kezie & 843.68 & 850.93 & 1176.48 & 1191.19 & 246.67 & 233.61 & 173.72 & 166.06 & 24.73 & 25.42 & 25.01 & 26.09 \\
\hline $\mathrm{C}_{2-}$ Chongloiman & 849.72 & 865.09 & 1295.85 & 1310.52 & 192.61 & 197.61 & 191.35 & 193.19 & 26.32 & 27.05 & 27.70 & 28.27 \\
\hline $\mathrm{C}_{3^{-}}$Leikhumo & 710.44 & 731.25 & 1114.00 & 1128.07 & 159.17 & 161.06 & 127.32 & 126.27 & 23.83 & 24.48 & 22.03 & 23.70 \\
\hline $\mathrm{C}_{4^{-}}$Kotsala & 778.67 & 800.15 & 1130.84 & 1145.38 & 163.78 & 160.50 & 141.89 & 145.56 & 23.92 & 24.55 & 23.56 & 25.35 \\
\hline SEd \pm & 40.00 & 33.52 & 39.64 & 43.92 & 24.83 & 17.05 & 19.40 & 14.75 & 1.19 & 1.12 & 1.27 & 1.10 \\
\hline $\mathrm{CD}(\mathrm{P}=0.05)$ & 87.17 & 73.04 & 86.37 & 95.71 & 54.10 & 37.14 & 42.28 & 32.14 & NS & NS & 2.76 & 2.39 \\
\hline \multicolumn{13}{|l|}{ Weed Management: } \\
\hline $\begin{array}{l}W_{0^{-}} \text {Unweeded } \\
\text { control }\end{array}$ & 602.25 & 586.29 & 936.47 & 931.12 & 51.25 & 94.96 & 104.06 & 93.68 & 17.74 & 19.09 & 9.07 & 10.09 \\
\hline $\begin{array}{l}W_{1} \text { - Handweeding at } \\
20 \text { and } 40 \text { DAS }\end{array}$ & 952.27 & 989.09 & 1343.03 & 1358.66 & 288.46 & 257.17 & 204.61 & 215.55 & 29.13 & 29.64 & 34.21 & 35.71 \\
\hline $\begin{array}{l}\text { W2- Butachlor @ } 1.5 \\
\text { kg a.i/ha + hand } \\
\text { weeding at } 40 \text { DAS }\end{array}$ & 832.36 & 860.18 & 1258.38 & 1291.59 & 231.96 & 212.46 & 167.04 & 164.08 & 27.23 & 27.39 & 30.45 & 31.75 \\
\hline SEd \pm & 17.44 & 27.12 & 30.29 & 28.83 & 17.83 & 8.23 & 14.19 & 9.08 & 0.79 & 0.96 & 0.90 & 0.77 \\
\hline $\mathrm{CD}(\mathrm{P}=0.05)$ & 35.52 & 55.24 & 61.71 & 58.73 & 36.31 & 16.76 & 28.90 & 18.51 & 1.61 & 1.95 & 1.83 & 1.58 \\
\hline
\end{tabular}


Table.3 Variation in weed growth attributes as affected by cultivars

\begin{tabular}{|c|c|c|c|c|c|c|c|c|c|c|c|c|}
\hline \multirow[t]{3}{*}{ Treatments } & \multicolumn{4}{|c|}{ Weed population (no./m²) } & \multicolumn{4}{|c|}{ Weed dry weight $\left(\mathrm{g} / \mathrm{m}^{2}\right)$} & \multirow{2}{*}{\multicolumn{2}{|c|}{$\begin{array}{l}\text { Weed RGR } \\
(30-60 \text { DAS) }\end{array}$}} & \multirow{2}{*}{\multicolumn{2}{|c|}{ WCE }} \\
\hline & \multicolumn{2}{|c|}{$30 \mathrm{DAS}$} & \multicolumn{2}{|c|}{60 DAS } & \multicolumn{2}{|c|}{30 DAS } & \multicolumn{2}{|c|}{60 DAS } & & & & \\
\hline & 2009 & 2010 & 2009 & 2010 & 2009 & 2010 & 2009 & 2010 & 2009 & 2010 & 2009 & 2010 \\
\hline \multicolumn{13}{|l|}{ Cultivars: } \\
\hline \multirow[t]{2}{*}{$\mathrm{C}_{1}$-Kezie } & 23.63 & 22.04 & 19.22 & 18.14 & \multirow[t]{2}{*}{99.97} & \multirow[t]{2}{*}{94.69} & \multirow[t]{2}{*}{144.16} & \multirow[t]{2}{*}{139.74} & \multirow[t]{2}{*}{0.0176} & \multirow[t]{2}{*}{0.0166} & \multirow[t]{2}{*}{60.61} & \multirow[t]{2}{*}{61.94} \\
\hline & $(557.88)$ & $(485.26)$ & $(368.91)$ & $(328.56)$ & & & & & & & & \\
\hline \multirow{2}{*}{$\mathrm{C}_{2^{-}}$Chongloiman } & 23.13 & 21.53 & 18.57 & 17.46 & \multirow[t]{2}{*}{97.06} & \multirow[t]{2}{*}{92.03} & \multirow[t]{2}{*}{141.28} & \multirow[t]{2}{*}{136.86} & \multirow[t]{2}{*}{0.0176} & \multirow[t]{2}{*}{0.0164} & \multirow[t]{2}{*}{60.93} & \multirow[t]{2}{*}{62.14} \\
\hline & $(534.50)$ & $(463.04)$ & $(344.34)$ & $(304.35)$ & & & & & & & & \\
\hline \multirow{2}{*}{$\mathrm{C}_{3-}$ Leikhumo } & 26.50 & 25.12 & 22.16 & 21.27 & \multirow[t]{2}{*}{106.05} & \multirow[t]{2}{*}{101.45} & \multirow[t]{2}{*}{157.39} & \multirow[t]{2}{*}{152.80} & \multirow[t]{2}{*}{0.0152} & \multirow[t]{2}{*}{0.0133} & \multirow[t]{2}{*}{60.07} & 61.33 \\
\hline & $(701.75)$ & $(630.51)$ & $(490.57)$ & $(451.91)$ & & & & & & & & \\
\hline $\mathrm{C}_{4}-$ Kotsala & 24.99 & 23.47 & 20.56 & 19.60 & 102.41 & 97.45 & 149.92 & 145.50 & 0.0148 & 0.0127 & 60.24 & 61.59 \\
\hline & $(624.00)$ & $(550.34)$ & $(422.21)$ & $(383.66)$ & & & & & & & & \\
\hline SEd \pm & 0.89 & 0.96 & 0.94 & 1.01 & 2.60 & 2.51 & 5.06 & 4.85 & 0.0009 & 0.0008 & 0.23 & 0.25 \\
\hline $\mathrm{CD}(\mathrm{P}=0.05)$ & 1.94 & 2.09 & 2.05 & 2.20 & 5.67 & 5.47 & 11.02 & 10.57 & 0.0019 & 0.0018 & 0.49 & 0.54 \\
\hline
\end{tabular}

Figures in parenthesis represent original values

Table.4 Variation in weed growth attributes as affected by weed management treatments

\begin{tabular}{|c|c|c|c|c|c|c|c|c|c|c|c|c|}
\hline \multirow{3}{*}{ Treatments } & \multicolumn{4}{|c|}{ Weed population (no./m²) } & \multicolumn{4}{|c|}{ Weed dry weight $\left(\mathrm{g} / \mathrm{m}^{2}\right)$} & \multirow{2}{*}{\multicolumn{2}{|c|}{$\begin{array}{l}\text { Weed RGR } \\
\text { (30-60 DAS) }\end{array}$}} & \multirow{2}{*}{\multicolumn{2}{|c|}{ WCE }} \\
\hline & \multicolumn{2}{|c|}{30 DAS } & \multicolumn{2}{|c|}{$60 \mathrm{DAS}$} & \multicolumn{2}{|c|}{$30 \mathrm{DAS}$} & \multicolumn{2}{|c|}{60 DAS } & & & & \\
\hline & 2009 & 2010 & 2009 & 2010 & 2009 & 2010 & 2009 & 2010 & 2009 & 2010 & 2009 & 2010 \\
\hline \multicolumn{13}{|c|}{ Weed Management: } \\
\hline \multirow[t]{2}{*}{$\mathrm{W}_{0}$} & 36.94 & 35.50 & 41.93 & 41.93 & \multirow[t]{2}{*}{192.34} & \multirow[t]{2}{*}{186.03} & \multirow[t]{2}{*}{416.70} & \multirow[t]{2}{*}{407.38} & \multirow[t]{2}{*}{0.0129} & \multirow[t]{2}{*}{0.0134} & \multirow[t]{2}{*}{0.00} & \multirow[t]{2}{*}{0.00} \\
\hline & (1364.06) & (1259.75) & (1757.62) & (1757.62) & & & & & & & & \\
\hline $\mathbf{W}_{1}$ & 10.61 & 9.61 & 9.03 & 9.03 & 10.46 & 8.82 & 13.53 & 11.00 & 0.0177 & 0.0150 & 92.57 & 94.64 \\
\hline \multirow[t]{2}{*}{$\mathbf{W}_{2}$} & 26.13 & 24.01 & 9.42 & 9.42 & \multirow[t]{2}{*}{101.32} & \multirow[t]{2}{*}{94.37} & \multirow[t]{2}{*}{14.33} & \multirow[t]{2}{*}{12.80} & \multirow[t]{2}{*}{0.0183} & \multirow[t]{2}{*}{0.0158} & \multirow[t]{2}{*}{88.81} & \multirow[t]{2}{*}{90.61} \\
\hline & $(682.28)$ & $(575.98)$ & $(88.24)$ & $(88.24)$ & & & & & & & & \\
\hline SEd + & 0.71 & 0.75 & 0.75 & 0.79 & 2.05 & 2.08 & 4.21 & 4.01 & 0.0003 & 0.0003 & 0.18 & 0.20 \\
\hline $\mathrm{CD}(\mathrm{P}=0.05)$ & 1.45 & 1.53 & 1.53 & 1.60 & 4.17 & 4.24 & 8.57 & 8.17 & 0.0007 & 0.0006 & 0.36 & 0.41 \\
\hline
\end{tabular}

$\mathrm{W}_{0^{-}}$Unweeded control, $\mathrm{W}_{1^{-}}$Handweeding at 20 and $40 \mathrm{DAS}, \mathrm{W}_{2^{-}}$Butachlor @ $1.5 \mathrm{~kg}$ a.i $/ \mathrm{ha}+$ hand weeding at 40 DAS

Figures in parenthesis represent original values; NS: Non-significant 


\section{Yield and yield attributes}

Significant variations in rice yield and yield attributes were recorded among the different cultivars (Table 2). Kezie recorded the highest number of panicles $/ \mathrm{m}^{2}$, which was significantly higher as compared to Leikhumo and Kotsala whereas, Chongloiman was also found to be at par with the cultivar Kezie. Higher number of tillers recorded by Kezie may be attributed for higher number of panicles as recorded by the cultivar. Hussain et al., (2014) also reported that higher number of panicles $/ \mathrm{m}^{2}$ in rice was due to more number of tillers and proportion of effective tillers. The cultivar Chongloiman was found to record significantly higher number of filled grains/panicle and grain yield $(27.70 \mathrm{q} / \mathrm{ha}$ and $28.27 \mathrm{q} / \mathrm{ha}$ during 2009 and 2010 respectively) as compared to Leikhumo (grain yield - 22.03 and 23.70 q/ha during 2009 and 2010 respectively) and Kotsala (grain yield 23.56 and 25.35 q/ha during 2009 and 2010 respectively) whereas, Kezie was also found to record significantly higher number of filled grains/panicle and grain yield $(25.01 \mathrm{q} / \mathrm{ha}$ and $26.09 \mathrm{q} / \mathrm{ha}$ during 2009 and 2010 respectively) compared to the cultivar Leikhumo. Variations in yield attributes and grain yield could be due to the genetic potential of the cultivars. Ashrafuzzaman et al., (2009) also found variation in morphological and yield components in different varieties of aromatic rice. Higher dry matter accumulation, LAI and number of filled grains as recorded by both Chongloiman and Kezie and higher number of tillers and panicles $/ \mathrm{m}^{2}$ recorded by Kezie may also be attributed for higher grain yields as recorded by both the cultivars. Association of growth attributes viz., LAI and dry matter production (Reddy and Reddy, 2010), number of productive tillers (Sheela and Alexander, 1995) and yield attributes viz., percent filled grain (Satapathy and Nanda, 1978), low sterility percentage (Sheela and Alexander,
1995) has also been reported by other researchers. 1000 grain weight was found to be non-significant among the different cultivars. The cultivars Kezie and Chongloiman were also found to record significantly lower weed population and density and higher weed control efficiency (WCE) as compared to Leikhumo and Kotsala which may have facilitated efficient utilization of the various growth resources and better expression of yield attributes and thereby resulting in higher grain yield. Lemerle et al., (2001) also stated that the morphological and physiological traits of a strongly competitive crop would enable it to capture resources from a weed, or utilize resources more efficiently.

The different weed management treatments were observed to record significant variations in grain yield and yield attributes (Table 2). Hand weeding at 20 and 40 DAS $\left(\mathrm{W}_{1}\right)$ was found to record significantly higher yield attributing characters viz., number of panicles $/ \mathrm{m}^{2}$, number of filled grains/panicle and 1000 grain weight compared to both application of butachlor @ $1.5 \mathrm{~kg}$ a.i./ha + hand weeding at 40 DAS $\left(\mathrm{W}_{2}\right)$ and unweeded control $\left(\mathrm{W}_{0}\right)$. Whereas, the treatment $\mathrm{W}_{2}$ was also found to record significantly higher values of the above mentioned yield attributing characters as compared to $\mathrm{W}_{1}$. Mishra (2016) and Ramana Murthy and Reddy (2013) also reported that hand weeding at 20 and 40 DAS produced the highest number of panicles $/ \mathrm{m}^{2}$, total number of grains/panicle and number of filled grains/panicle whereas unweeded check recorded the lowest values of these parameters. Significantly lower weed growth as recorded by the treatments $\mathrm{W}_{1}$ and $\mathrm{W}_{2}$ may have resulted in increased availability of growth resources to the crop resulting in better crop growth and development thereby exhibiting superior yield attributes. The highest grain yield of $34.21 \mathrm{q} / \mathrm{ha}$ during 2009 
and $35.71 \mathrm{q} /$ ha during 2010 was recorded by the treatment $\mathrm{W}_{1}$ which was followed by $\mathrm{W}_{2}$ (30.45 q/ha and $31.75 \mathrm{q} / \mathrm{ha}$ during 2009 and 2010) whereas, $W_{0}$ recorded the lowest grain yield during both years $(9.07 \mathrm{q} / \mathrm{ha}$ and 10.09 q/ha during 2009 and 2010). Ramana Murthy and Reddy (2013) also reported that hand weeding at 20 and 40 DAS recorded the highest grain and straw yields whereas, Pandey (2009) also reported the lowest grain yield under unweeded check. Significantly higher grain yield associated with $\mathrm{W}_{1}$ and $\mathrm{W}_{2}$ may be due to better expression of growth and yield components owing to superior weed control. Baharat Bhushan Rao et al., (2000) also reported that grain yield could be associated with production of higher dry matter, greater number of productive tillers, heavier panicle, number of total grains/panicle, sterility per cent and 1000 grains weight.

Among the four cultivars tested, Chongloiman and Kezie were found to exhibit significantly better crop growth and yield attributes with significantly higher grain yields of $27.70 \mathrm{q} / \mathrm{ha}$ and $25.01 \mathrm{q} / \mathrm{ha}$ during 2009 and $28.27 \mathrm{q} / \mathrm{ha}$ and $26.09 \mathrm{q} / \mathrm{ha}$ during 2010 respectively. Significantly lower weed population, weed dry weight and weed RGR and higher weed control efficiency were also recorded by the cultivars Kezie and Chongloiman. Among the weed management treatments, hand weeding at 20 and 40 days after sowing was found to record significantly higher weed control efficiency with significantly lower weed population and dry weight resulting in better crop growth and superior yield attributes and ultimately recording the highest grain yield of $34.21 \mathrm{q}$ and $35.71 \mathrm{q} / \mathrm{ha}$ during 2009 and 2010 respectively. Application of butachlor @ 1.5 $\mathrm{kg}$ a.i./ha + hand weeding at 40 DAS was also found to record significantly lower weed growth and better crop growth and grain yield (30.45 q/ha and $31.75 \mathrm{q} /$ ha during 2009 and 2010) compared to unweeded control.

\section{References}

Andrew, K.S., Storkey, J. and Sparkes, D. L. 2015. A review of the potential for competitive cereal cultivars as a tool in integrated weed management. Weed Res., 55: 239 - 248.

Ashrafuzzaman, M., Islam, M. R., Ismail, M. R., Shahidullah, S. M. and Hanafi, M. M. 2009. Evaluation of six aromatic rice varieties for yield and yield contributing characters. Int. J. of Agri. and Bio. 11: $616-620$.

Barman, K. K. and Varshney, J. G. 2008. Impacts of herbicide on soil environment. Indian J. of Weed Sci., 40(1\&2): 10 - 17.

Bharat Bhushan Rao, C. H., Modh, I. and Murthy, R. 2000. Influence of time of planting on grain yield of scented rice. Crop Res., 20: 179 - 181.

Buhler, D. D., Liebman, M. and Obrycki, J. J. 2000. Theoretical and practical challenges to an IPM approach to weed management. Weed Sci., 48: 274 - 280.

Cousens, R. D, Barnett, A. G. and Barry, G. C. 2003. Dynamics of competition between wheat and oat: I. Effect of changing the timing of phenological events. Agronomy J., 95:1295 - 1304.

DES, 2015. Statistical handbook of Nagaland. Directorate of Economics and Statistics. Government of Nagaland.

Fischer, A. J. and Gibson, K. D. 2001. Cultivares competitivos como herramienta para el Manejo Integrado de Malezas. Resúmenes XV Congreso ALAM, Maracaibo, Venezuela, 26-30 Nov., pp. 71-72.

Fukai, S. 2002. Rice cultivar requirement for direct-seeding in rainfed lowlands. In S. Pandey, M. Mortimer, L. Wade, T. P. Tuong, K. Lopez and B. Hardy (Ed.), Direct seeding: Research strategies and opportunities. Proceedings of the international workshop on direct seeding in Asian rice systems: Strategic 
research issues and opportunities. 2528 Jan., 2000. pp. 15 - 39.

Haefele, S. M., Johnson, D. E., M'bodj, D. M., Wopereis, M. C. S. and Miezan, K. M. 2004. Field screening of diverse rice genotypes for weed competitiveness in irrigated lowland ecosystems. Field Crops Res., 88: 39 - 56.

Hooda, I. S. 2002. Weed management in organic rice. In: Development of basic standard for organic rice cultivation, $1^{\text {st }}$ RDA/ARNOA international conference, 12-15 Nov., RDA and Dankook University, Korea.

Hussain, S., Fujii, T., McGoey, S., Yamada, M., Ramzan, M. and Akmal, M. 2014. Evaluation of different rice varieties for growth and yield characteristics. The $J$. of Animal \& Plant Sci., 24(5): 1504 1510 .

Jayadeva, H. M., Bhairappanavar, S. T., Hugar, A. Y., Rangaswamy, B. R., Mallikarjun, G. B., Malleshappa, C. and Channa Naik, D. 2011. Integrated weed management in aerobic rice (Oryza sativa L.). Agril, Sc. Digest 31(1): 58 61.

Lakshmanon, A. R., Panneerselvam and Kathiersam, R. M. 1984. Chemical weed control in transplanted IR- 50 Rice. In Annual Conference of Indian Society of Weed Science, Abstracts of papers. $4-5^{\text {th }}$ April. p. 4.

Lemerle, D., Gill, G. S., Murphy, C. E., Walker, S. R., Cousens, R. D, Mokhtari, S., Peltzer, S. J., Coleman, R. and Luckett, D. J. 2001. Genetic improvement and agronomy for enhanced wheat competitiveness with weeds. Australian J. of Agril. Res., 52: 527-548.

Mandal, B. K, Ghori, A. K. and Mandal, B. K. 1986. Relative efficiency of selected herbicides for controlling weeds in transplanted rice. Oryza. 23(4): 242 248.
Mirza, H., Kamrun, N. and Md. Rezaul, K. 2007. Effectiveness of different weed control methods on the performance of transplanted rice. Pakistan J. of Weed Sc. Res., 13: 17 - 25.

Mishra, L. N. 2016. Assessment of chemical and non-Chemical Weed management strategies in direct- Seeded aerobic rice (Oryza sativa L.). M.Sc. (Ag.) Thesis. Indira Gandhi Krishi Vishwavidyalaya, Raipur.

Mohammad, T., Deva, W. and Ahmad, Z. 2002. Genetic variability of different plant and yield characters in rice. Sarhad J. of Agri., 18: 207 - 210.

Pandey, S. 2009. Effect of weed control methods on rice cultivars under the system of rice intensification (SRI). M.Sc. Thesis. Institute of Agriculture and Animal Science, Rampur, Chitwan, Nepal.

Patel, S. R., Lal, N. and Thakur, D. S. 1997. Integrated weed management in direct seeded rice (Oryza sativa L.) under rainfed condition. In International symposium on rainfed rice production strategy for $21^{\text {st }}$ century, 25-27 November 1997, Assam Agricultural University, Jorhat. p. 97.

Ramana Murthy, K. V. and Reddy, D. S. 2013. Effect of irrigation and weed management practices on nutrient uptake and economics of production of Aerobic rice. IOSR J. of Agri. and Vety. Sci., 3(1): 15 - 21.

Rao, A. N., Johnson, D. E., Sivaprasad, B., Ladha, J. K., and Mortimer, A. M. 2007. Weed management in directseeded rice. Advances in Agronomy. 93: $153-255$.

Reddy, T. Y. and Reddy, G. H. S. 2010. Growth and development of crops. Principles of Agronomy. Kalyani Publishers, New Delhi.

Saikia, J. 1991. Weed control in rice based cropping system. M.Sc (Ag.) Thesis, 
Assam Agricultural University, Jorhat.

Satapathy, D. and Nanda, A. K. 1978. Interrelationship between yield and some associated characters in upland rice grown under rainfed conditions. Oryza. 15: 12 - 18 .

Sheela, K. R. and Alexander, V. T. 1995. Performance of rainfed rice (Oryza sativa) as influenced by varieties and nutrient levels. Indian J. of Agronomy.
40: 407 - 411.

Zhao, D.L., Atlin, G. N., Bastiaans, L. and Spiertz, J.H. J. 2006. Cultivar weed competitiveness in aerobic rice: Heritability, correlated traits, and the potential for in direct selection in weedfree environment. Crop Science. 46: 372 - 380 .

\section{How to cite this article:}

Noyingthung Kikon, T. Gohain, N. Khumdemo Ezung and Angami, T. 2018. Crop and Weed Growth in Direct-Seeded Rice Cultivars as affected by Different Weed Management Practices under Rainfed Conditions of Nagaland. Int.J.Curr.Microbiol.App.Sci. 7(02): 590-601. doi: https://doi.org/10.20546/ijcmas.2018.702.074 